DOI: https://doi.org/10.32782/2410-0927-2020-13-20

УДК $811.111 .81 ’ 373.49$

Леся Небелюк

\title{
КОНЦЕПТУАЛЬНА МЕТОНІМІЯ ЯК ОСНОВА ЕВФЕМІЗМІВ АМЕРИКАНСЬКОГО АНГЛОМОВНОГО ПОЛІТИЧНОГО ДИСКУРСУ
}

У статті проаналізовано евфемізми американського англомовного політичного дискурсу, в основу яких закладено концептуальну метонімію. Виявлено, що деякі евфемізми в політичному дискурсі не розпізнаються реципієнтами як такі, проте евфемістичний потенціал цих евфемізмів не зменшується. Досліджено, що концептуальна метонімія може бути одним із когнітивних механізмів творення прихованих смислів евфемізмів $\mathrm{i}$ може надавати їм непомітності в політичному дискурсі. Показано лексико-семантичні зв'язки зі сфер знань реципієнта, що сприяють позитивному сприйняттю евфемізмів через концептуальну метонімію. Застосовано теорію концептуальної метонімії до вивчення лінгвокогнітивних характеристик досліджуваних евфемізмів. Аналізуючи лінгвокогнітивні характеристики евфемізмів американського англомовного політичного дискурсу із застосуванням теорії концептуальної метонімії, ми виявили, що концептуальна метонімія ЦІЛЕ замість ЧАСТИНИ ввійшла до основ 10 досліджуваних евфемізмів, а саме: alternative, strategic, affordable, progressive, radical, rational, informal, adjustment, procedure, action. Досліджувані евфемізми виокремлено шляхом вибірки із політичних текстів періодичних видань "The Washington Post" and "The New York Times" 2000 - 2020 рр. Установлено, що концептуальна метонімія ЦІЕ замість ЧАСТИНИ може слугувати когнітивною основою для творення евфемізмів $\mathrm{i}$ в результаті такої метонімічної концептуалізації негативні факти репрезентуються деякими значно ширшими, але позитивнішими або нейтральними поняттями. Описано асоціативне сприйняття досліджуваних евфемістичних одиниць реципієнтами й виявлено, що евфемізми, основані на концептуальній метонімії ЦІЛЕ замість ЧАСТИНИ, завуальовують негативні факти саме не фокусуючи на них увагу, змушуючи реципієнта мимовольної опустити негативний факт. Визначено, що досліджувані евфемізми можуть впливати на когніцію реципієнта саме через уключення негативного факту до ширшого позитивнішого або нейтрального концепту, у результаті чого виникатиме більш позитивна або нейтральна реакція реципієнта на негативне політичне явище.

Ключові слова: евфемізм, концептуальна метонімія, політичний дискурс, когнітивний механізм, асоціативне сприйняття.

Вступ. Одними із засобів із яскраво вираженими вуалітивними функціями є евфемізми, які широко застосовуються в політичному дискурсі. Їх широке використання пов'язане з тим, що все частіше з'являються негативні факти, які потребують позитивнішого та не надто різкого подання реципієнтам. Дослідження евфемізмів до сьогодні здебільшого проводили в рамках стилістичних, лексико-семантичних чи функціонального-прагматичних розвідок [2; 5]. В. Великорода стверджує, що наукові праці та монографії (А. Кацев, Н. Босчаєва, К. Хем, Дж. Лоуресн, В. Ноубл, К. Аллан, К. Баррідж， І. Алексєєв， С. Відлак， В. Кравченко， Б. Ларін), засвідчують виникнення різних підходів до трактування явища евфемізації в англійській мові. Розбіжності стосуються способів творення евфемізмів, визначення мотивів їх уживання мовцями, класифікації евфемічної лексеми, сфер дистрибуції евфемізмів, їхніх прагматичних особливостей функціонування та стильової належності [6, с. 1]. Проте лінгвокогнітивні характеристики евфемізмів й когнітивні процеси евфемізації небажаних аспектів реальності в політичному дискурсі залишаються поза увагою лінгвістів, що й спонукало до написання цієї статті.

Евфемізми часто $є$ непомітними, «прихованими» в політичному дискурсі та не виокремлюються реципієнтами як такі, оскільки вони виражені ширшими, але позитивнішими або нейтральними поняттями, які, власне, уключають у себе негативне явище, яке позначає евфемізм. Тобто ці евфемізми утворені на основі когнітивного механізму концептуальної метонімії ЦІЛЕ замість ЧАСТИНИ. Отже, мета статті $-\epsilon$ аналіз лінгвокогнітивних характеристик евфемізмів, утворених на основі концептуальної метонімії ЦІЛЕ замість ЧАСТИНИ, в американському англомовному політичному дискурсі. Відповідно до поставленої мети завданням статті є опис когнітивного впливу та особливостей асоціативного сприймання цих одиниць.

Методи та методики дослідження. Поняття евфемізму ми трактуємо за визначенням В. Б. Великороди: «Евфемізми - одиниці вторинної номінації 3 відносно позитивною конотацією, що використовують для заміни прямих найменувань, уживання яких із соціально чи психологічно зумовлених причин вважається небажаним» [6, с.5]. Матеріалом дослідження

(С) Небелюк Л., 2020 
стали політичні евфемізми, виявлені в періодичних англомовних виданнях "The New York Times" та "The Washington Post" $2000-2020$ pp.

Досліджуючи евфемізми американського політичного дискурсу, ми зауважили широке вживання евфемістичних одиниць, котрі, на перший погляд, ними не видаються, легко інтерпретуються реципієнтами, але водночас завуальовують негативний аспект явища. Найчастіше вони його нейтралізують, просто не наголошуючи на ньому, уключаючи його до ширшого поняття. Ми також зауважили, що евфемізмами часто виступають широко застосовувані лексичні одиниці, які позначають дуже широкі поняття і можуть уключати різні значення, навіть полярні відносно одне одного в умовах відповідного контексту. Ми простежили, що в основу цих евфемізмів закладено концептуальну метонімію ЦІЛЕ замість ЧАСТИНИ.

Опираючись на концепцію 3. Кевечеша й Г. Раддена, помічаємо, що метонімія $\epsilon$ когнітивним процесом, у якому один концепт-джерело (джерело) забезпечує ментальний доступ до другого концепту-цілі (ціль) у межах одного домена (сфери), або ідеалізованої концептуальної моделі [3, с. 42]. Когнітивний підхід до метонімії надає ій статусу одного зі способів формування знання про світ у вигляді особливих ментальних структур - метонімічних концептів. Метонімічні концепти, які дають змогу осмислити одну сутність у рамках ії зв'язків з іншими сутностями, $\epsilon$ складовою частиною повсякденного мислення, способів мовлення й поведінки [5, с. 63]. Метонімія $є$ мотивованою фізичними та причинними асоціаціями. Традиційно це виражено через термін суміжності тобто близьких або прямих зв'язків між двома об'єктами [1, с. 17]. Отже, один об'єкт може виступати замість іншого, тому що обидва концепти співіснують у межах однієї й тієї самої сфери. Це пояснює, чому метонімічні зв’язки грунтуються на суміжності чи концептуальній «близькості», адже метонімія $є$ референційною за своєю природою. Вона вживається 3 метою скерувати, направити, указати на об'єкти чи явища, про які йдеться [1, с. 17]. У випадку 3 концептуальною метонімією ЦІЛЕ замість ЧАСТИНИ метою $\epsilon$, власне, прагнення не висловлюватися точно, не спрямувати адресата, а заплутати його, не звернути його увагу, а зробити так, щоб він не помітив цей концепт. У такому випадку референт уключає в себе корелят, a також ще й низку понять. Отже, інформаційно важливе може пропускатися, a загальнозрозуміле - підкреслюватися, спостерігаємо метонімічну генералізацію.

Оскільки метонімія як концептуальне явище $\epsilon$ категорією мислення, процесом розширення значень і формуванням смислів, вона $\epsilon$ зручним засобом для механізму творення евфемізмів [6, с. 5], тому що мета евфемізму - це часто завуалювання негативного концепту саме через репрезентацію якогось ширшого менш негативно чи нейтрального концепту, узагальнюючи негативний концепт з іншими суміжними не такими негативними концептами.

Результати та дискусії. До нашої вибірки увійшли такі евфемічні прикметники, які узагальнюють, а не конкретизують негативне явище (у дужках даємо евфемістичне значення зі словника евфемізмів): alternative (differing from existing social arrangement, practicality or convention), strategic (seeks to indicate failure or an action taken under compulsion), tactical (done involuntary under pressure), planned (unexpected and unwelcome; common usage when we prefer not to admit that we have been wrong or lacking in forsight), affordable (cheap), progressive (opposed to conventional manners or methods), radical (accepting or advocating extreme political policies), rational (agreeing with a prejudice), informal (acting illegally or without required permission; literary, casual or easy-going) [2]. Проаналізуємо їх детальніше та проілюструємо їх вживання в публікаціях американських англомовних періодичних видань 3МI.

"When Trump said he was targeting Iranian sites including those "important to Iran \& the Iranian culture," which would have run afoul of international law, Conway again stepped forward to argue the unarguable. She explained that the country had many "strategic military sites that you may cite are also cultural sites.”" (The Washington Post, 24/08/2020 ). Евфемізм strategic потрібно сприймати з особливою пересторогою, оскільки в прямому сенсі strategic означає щось надто важливе та ще й згідно з планом [4]. Проте бачимо, що знищувати іранську культурну спадщину не зовсім було за планом, а якщо й за планом, то неморально чи неетично, але якщо назвати це військовою стратегічною ціллю, то ці дії будуть виправдані й сприйматимуться, як щось необхідне для військової операції. В основі цього евфемізму простежуємо концептуальну метонімію ЦІЛЕ замість ЧАСТИНИ, де цілим буде стратегічна споруда, а частиною - споруда 
культурної спадщини, адже єдиного визначення для стратегічного місця чи споруди немає. За різних умов та суджень будь-що може стати стратегічним. Саме тому цей евфемізм потрібно сприймати з пересторогою й увагою, адже він спроможний завуалювати будь-яке негідне явище.

"At my loan brokerage firm, we help clients arrange loans from both traditional banks and alternative lenders - depending on the circumstances. The bank loans we see have been charging interest rates ranging from 4 to 6 percent with a typical amortization period of five to 25 years. With alternative lenders, the rates can range from 20 to 200 percent with a typical amortization of six to 12 months" (The New York Times, 30/09/2013). Alternative як пряма номінація означає дію, ідею тощо, але таку, що відрізняється від наявної й може бути використана замість неї [4]. Прикметник, який нейтралізує як позитивне, так і негативне значення та означає просто інший, щось натомість. Альтернатива не сприймається мовцями як гірший варіант, а як явище з тієї самої категорії, що й основний варіант, і як такий, котрий призведе до таких самих результатів. Проте якщо клієнту не дають кредит у банку та він звертається до альтернативних кредиторів, значить банк поставив під сумнів можливість сплатити кредит клієнтом. 3 одного боку, альтернативні кредитори звучить як порятунок для тих, хто потребує великих сум грошей, а з іншого - саме через таких кредиторів люди залишаються розореними повністю, не сплативши шалені відсотки. Простежуємо концептуальну метонімію ЦІЛЕ замість ЧАСТИНИ, де цілим є альтернатива загалом у широкому розумінні цього евфемізму, не лише посилаючись на вищенаведений приклад, а частиною є ненайкращчий варіант. Адже альтернативні кредитори пропонують більші відсотки й коротший термін сплати кредиту, що є гіршим варіантом для клієнта.

"I want to see affordable housing as part of the infrastructure program going forward, and I want to see the building of schools in rural communities, good, efficient schools for rural children" (The Washington Post, 30/10/2020). Доступне житло сприймається краще, ніж дешеве. Afford як пряме значення означає мати достатньо коштів для придбання чогось, affordable (доступний) - це прикметник, що означує власне конкретний предмет, для придбання якого $є$ достатньо коштів [4]. Поняття доступне є досить широким, у кожного реципієнта свій рівень доступності, для заможних громадян теж щось $є$ доступним, а щось - ні. Отже, бідність вуалізується через міру доступності чогось. Виникає ілюзія, що бідності нема, а лише ступінь доступності, який у кожного різний. Отже, не виникає різко негативних реакцій у реципієнтів, оскільки поняття доступність визначається радше як достатність коштів, аніж як брак коштів. Простежуємо концептуальну метонімію ЦІЛЕ замість ЧАСТИНИ, де доступність є цілим, а дешевизна - його частиною.

"All of this puts progressive Jews like myself in an extraordinarily difficult position. We often refrain from calling out anti-Semitism on our side for fear of our political bona fides being questioned..."'(The New York Times 14/11/ 2019). “A few facts ought at least to stir the thinking of those who subscribe to the progressive_narrative" (The New York Times, 08/02/ 2019). Progressive y прямому значенні визначається як такий, що підтримує нові сучасні ідеї та методи [4]. У політичному дискурсі як евфемізм воно ж уживається для позначення чогось незвичного, відмінного від усталених норм, часто прикриваючи певні різкі дії чи висловлювання, що $\epsilon$ неприйнятними для думки, що існує у суспільстві. Реципієнт сам вибирає конкретне розуміння «прогресивний» або просто не акцентує уваги на ньому. Це і $є$ мета таких евфемізмів - якщо не покращити негативне значення, то зробити його непомітним. Знову бачимо концептуальну метонімію в основі цього евфемізму ЦІЛЕ замість ЧАСТИНИ, де прогресивний буде цілим, а щось відмінне від усталених норм, неприйнятне - частиною.

"By refusing to allow the counting of mail ballots before Election Day, in the full knowledge that pandemic conditions would lead to an explosion of vote by mail, they've helped create the delays that Trump is now trying (but, mercifully, failing) to exploit to get vote counts halted. But that's not enough, we're told. They should go even further and take an extraordinarily radical step such as this" (The Washington Post, 05/11/ 2020). Radical у прямому сенсі означає велику й дуже важливу відмінність або зміну [4]. До цього й апелює евфемічний смисл. Але такий різко інший може включати й негативні нюанси, такі як спроба Трампа заборонити підрахунок голосів, що надходять поштою. Проте такий план Трампа подається як an extraordinarily radical step, що в перекладі - надзвичайно радикальний крок. Окрім того, extraordinarily в англійській мові має позитивну конотацію. 
Простежуємо метонімічну модель ЦІЛЕ замість ЧАСТИНИ, де у випадку з вищенаведеної цитати цілим буде радикальний крок, а частиною - заборона підрахунків поштою.

"Investors are afraid and uncertain these days. Given how hard it is to determine true asset prices, they are being completely rational" (The New York Times, 22/02/2009). "Today, at last, we have panic in surplus - however unevenly distributed and still-insufficient in some places. But now we need something else to leaven it: Along with rational panic, we need sources of rational hope" (The New York Times, 28/03/2020). "With commodity price pressure unlikely to abate, focusing on balance sheet stability might be the most rational strategy available" (The New York Times, 19/08/ 2015). Rational у прямій номінації означає такий, що керується скоріше розумом, ніж емоціями [4]. У випадках, коли потрібно погодитись із чимось несприятливим і схилити до цієї думки реципієнтів, дієвим $є$ апелювання до розуму й сенсу та називати такі речі раціональними. Отже, панікувати - це раціонально, а отже, розумно. Навіть згадка про причину, а потім указівка, що це раціонально, нейтралізує всю «гіркоту» явища не викликає збентеження, не акцентує, власне, на причині. Раціональне рішення в певній складній ситуації не завжди буде позитивним явищем, воно буде просто найрозумнішим і вигіднішим лише в тій певній ситуації й часто це може зовсім не влаштовувати реципієнтів. Раціональний - це радше найрозумніший із варіантів, але який не завжди буде позитивно сприйматися. Цей евфемізм може вживатися як виправдання неприємних політичних рішень. У метонімічній моделі ЦІЛЕ замість ЧАСТИНИ, яка є основою для евфемізму rational, цілим буде раџіональне рішення чи дія, а частиною - найменш збиткове чи найменш небезпечне рімення чи дія, утім, це не виключає негативного соціального явища.

"President Bush has been holding informal off-the-record sessions with major news organizations over the last several days" (The New York Times, March 28/03/2006). “... the Tibetan government in exile in India announced Friday that two envoys were on their way to an undisclosed location in China for "informal" discussions" (The New York Times, 03/05/ 2008). Informal y прямому значенні трактується як такий, що необмежений правилами прийнятої поведінки, як звичайний чи зручний [4]. Отже, неофіиійний не сприймається реципієнтами як незаконний, радше - як звичайний, буденний. Неофіційна подія відтак виглядає як така, що відбувається без зайвих приготувань, без пафосу, без певних вимог до поведінки, мови й одягу, але упускається 3 уваги той нюанс, що вона ще й відбувається, так би мовити, «поза кулісами». Результати таких подій чи домовленостей мають залишитися таємними, тобто вони ще й відбуваються поза законом. Отже, неофіиійний буде цілим, а незаконний - його частиною в метонімічній моделі ЦІЛЕ замість ЧАСТИНИ. Проте асоціації в реципієнта виникають швидше з повсякденністю, чимось несерйозним, а не з незаконною дією. Адже неофіиійинй уключає в себе будь-що, від форми одягу і до порушення закону.

Концептуальною метонімією ЦІЛЕ замість ЧАСТИНИ послуговуються також і такі евфемічні іменники: adjustment (the subjective alteration of public accounts), procedure (any taboo or unpleasant act), action (vice or illegal activity).

"The consequences of that are seen in Mosul and Raqqa, where the risk to civilians grew and grew, and there were no adjustments made, he said, referring to the intense 2016 - 2017 bombing campaigns in and around the Islamic State's twin capitals in Iraq and Syria, respectively" (The Washington Post, March 07/03/2019). Adjustment у прямому сенсі трактується як зміна чи регулювання [4]. Бомбардування - це, звісно, регулювання, а саме регулювання території, військових позицій, кількості населення, адже це руйнація й чисельна смертність. Подаючи цей факт як широке поняття, акцент на нищівній шкоді не робимо. У вищенаведеній цитаті евфемізм adjustment послуговується метонімічною моделлю ЦІЛЕ замість ЧАСТИНИ, де цілим виступатиме явище надзвичайно широкого розуміння регулювання (виправлення), а його частиною - бомбардування.

"A report this summer from the Migration Policy Institute outlined over 400 actions on immigration that had been enacted by a sprawling array of federal departments in the Trump era" (The New York Times, 10/10/ 2020 ). Action у прямому значенні трактується як процес виконання чогось. Це широке поняття може включати будь-що, як негативні, так і позитивні дії. 400 actions on immigration може означати як формальні бюрократичні дії, так і ув'язнення, застосування фізичної сили чи інші негативні дії щодо іммігрантів. "In person and on Twitter, Trump has 
targeted officials in several states, including from his own party, as he seeks to upend, discredit and invalidate the election and spread baseless claims that a victory was stolen from him. These are unprecedented actions for a modern president, but for Trump, they are standard operating procedure" (The Washington Post, 21/11/2020). Безпрещедентні дії сприймаються як такі, які ще ніколи не траплялися [4], вони могли б бути як законними, так і незаконними. Із контексту розуміємо, що йдеться про не зовсім порядні дії Трампа, проте безпрещедентні дї й оперуюча прочедура нейтралізують ці негативні явища, не наголошують на негативності, а прирівнюють до дій, котрі ще не траплялися. Procedure у прямому сенсі визначається як правильний або вже звичний спосіб виконання чогось [4]. Проте як евфемізм procedure може прикривати будь-яке ганебне діяння. Для евфемізму action із вищенаведених цитат властива метонімічна модель ЦІЛЕ замість ЧАСТИНИ, де цілим буде дія, а негативне чи ганебне діяння - його частиною. Адже дія настільки широке й узагальнене поняття, що може включити до себе в прямому сенсі будь-яке діяння. В останній цитаті також наявний евфемізм procedure, що послуговується тією самою метонімічною моделлю, де цілим буде процедура, а частиною, судячи з цитати - дискредитація виборів. Частиною процедури теж може бути будь-яка ганебна дія.

Висновки. Результати дослідження лінгвокогнітивних характеристик евфемізмів американського англомовного політичного дискурсу дають змогу стверджувати, що основою евфемізмів може бути концептуальна метонімія ЦІЛЕ замість ЧАСТИНИ. Отже, не акцентовано на конкретному негативному явищі, яке, навпаки, узагальнюється, уключається до концепту широкого розуміння з позитивнішою або нейтральною конотацією. Чим ширше поняття цілого, тим ганебніше й негативніше явище воно може прикривати, іноді категоріям генералізації (узагальнення) немає меж і вони можуть включати в себе надзвичайно велику кількість понять, як негативних, так і позитивних. За такої евфемізації політичного дискурсу у реципієнтів виникає ілюзія благополучності, успішності та безбідності, адже для пересічних громадян інформація, евфемізована таким чином, не передає чіткого повідомлення про негативний факт.

Отже, за допомогою концептуальної метонімії ЦІЛЕ замість ЧАСТИНИ евфемізми можуть вуалізувати негативні факти, репрезентуючи в мові певне широке поняття, яке включає в себе цей негативний факт як одну з його складових чи суміжних понять. Отже, негативний факт сприйматиметься не так гостро й прямо, оскільки небажані та різко негативні складники негативного явища залишаються наче в тіні, тобто є завуальованими.

Перспективами досліджень вважаємо аналіз лінгвокогнітивних характеристик евфемізмів, утворених на основі інших концептуальних метонімій.

\section{References}

1. Evans, Vyvyan \& Bergen, Benjamin \& Zinken, Jörg. 2007. The Cognitive Linguistics Enterprise: An Overview. The Cognitive Linguistics Reader. London: Equinox Publishing Ltd.

2. Holder, Richard. 2008. How Not to Say What You Mean: Dictionary of Euphemisms. NY: Oxford University Press Inc.

3. Kovecses, Zoltan. and Radden, Gunter. 1999. Towards a Theory of Metonymy. Metonymy in Language and Thought. Amsterdam and Philadelphia: Benjamins

4. Longman Exams Dictionary. 2006. UK: Pearson Education Ltd.

5. Lakoff, George \& Johnson, Mark. 2003. Metaphors we live by. Chicago: University of Chicago Press.

6. Velykoroda, Vira. 2008. "Semantychni ta funktsionalno-prahmatychni kharakterystyky evfemismiv $v$ anhliiskii movi’. PhD diss., Lviv.

Небелюк Леся. Концептуальная метонимия в основании эвфемизмов американского англоязычного политического дискурса. В статье анализируются эвфемизмы американского политического дискурса, в основание которого заложена концептуальная метонимия. Отмечается, что некоторые эвфемизмы в политическом дискурсе не распознаваемые реципиентами как такие, но их эвфемистический потенциал остается достаточно сильным. Доказывается, что концептуальная метонимия может быть одним из когнитивных механизмов создания скрытых смыслов эвфемизмов и может оказывать им незаметность в политическом дискурсе. Показывается лексикосемантические связи из сфер знаний реципиента, способствующих позитивному восприятию эвфемизмов через концептуальную метонимию. Применяется теория концептуальной метонимии к изучению лингвокогнитивных характеристик исследуемых эвфемизмов. Анализируя лингвокогнитивные характеристики эвфемизмов американского англоязычного политического дискурса с применением теории концептуальной метонимии мы обнаружили, что концептуальная метонимия ЦЕЛОЕ вместо ЧАСТИ содержится в основе исследуемых эвфемизмов, а именно: alternative, strategic, affordable, progressive, radical, rational, informal, adjustment, procedure, action. Исследуемые эвфемизмы выделяем путем выборки из политических текстов периодических изданий “Тһе 
Washington Post” и “The New York Times” 2000 - 2020 гг. Устанавливается, что концептуальная метонимия ЦЕЛОЕ вместо ЧАСТИ может служить когнитивной основой для создания эвфемизмов, и в результате такой метонимической концептуализации негативные факты представляются широкими, относительно позитивными или нейтральными понятиями. Описывается ассоциативное восприятие изучаемых эвфемистических единиц реципиентами и обнаружено, что эвфемизмы, основанные на концептуальной метонимии ЦЕЛОЕ вместо ЧАСТИ, вуалируют негативные факты не фокусируя на них внимание, заставляя реципиента самопроизвольно пропустить негативный факт. Определено, что исследуемые эвфемизмы могут влиять на когницию реципиента, именно благодаря включению негативного факта к более широкому позитивному или нейтральному концепту, в результате чего возникнет позитивная или нейтральная реакция реципиента на негативное политическое явление.

Ключевые слова: эвфемизм, концептуальная метонимия, политический дискурс, когнитивный механизм, ассоциативное восприятие.

Nebeliuk Lesia. Conceptual Metonymy in the basis of Euphemisms in the English Language American Political Discourse. The article deals with the analysis of euphemisms in the English language American political discourse based on conceptual metonymy. Though the phenomenon of euphemisation has been widely studied, the linguo-cognitive characteristics of euphemisms in the English language American political discourse and their influence on the recipients have not been established yet. The aim of the article is to analyze euphemisms in the English language American political discourse based on the conceptual metonymy. Some political euphemisms are not immediately recognized in the political discourse by the recipients, whereas the euphemistic potential remains quite strong. The author claims that the conceptual metonymy can be one of the cognitive mechanisms of creating hidden senses of the euphemisms and make these euphemisms unnoticeable in the discourse. The author provides lexical-semantic components from the addressee's spheres of knowledge that contribute to ameliorated, positive perception of the nominations, and applies the theory of conceptual metonymy to the euphemisms under study. The study of linguo-cognitive characteristics of euphemisms in the English language American political discourse applying the conceptual metonymy theory allows tracing the conceptual metonymy WHOLE as PART in the basis of such euphemisms: alternative, strategic, affordable, progressive, radical, rational, informal, adjustment, procedure, action. The euphemisms under study were selected from the political texts of "The Washington Post" and "The New York Times" 20002020. It was established that the conceptual metonymy may serve as a cognitive basis for the euphemisms under study. As a result of such metonymic conceptualization, negative facts are represented by some much wider but positive or neutral concepts. The author also describes the associative perception of the euphemisms under study. The analysis shows that euphemisms based on the conceptual metonymy WHOLE as PART make the recipients skip negative facts by not focusing on them. The euphemisms listed above are able to influence the recipient's cognition due to the inclusion of the negative fact to a wider more positive or neutral concept. The result is a positive or neutral recipient's reaction.

Key words: euphemism, conceptual metonymy, political discourse, cognitive mechanism, associative perception.

DOI: https://doi.org/10.32782/2410-0927-2020-13-21

УДК 159.922.76:376

Antonina Semeniuk, IrynaYezerska

\section{INCLUSIVE EDUCATION FOR PUPILS WITH AUTISTIC SPECTRUM DISORDERS}

In this article attention is paid to psychological adaptation of children with autistic spectrum disorder in the learning process. The appropriate strategies of teaching English as a foreign language to students with ASD that will supply their psychological adaptation in mainstream secondary schoolsare highlighted.The concept of inclusion is revealed and the basic principles of inclusive education are emphasized. Methods of learning words, sounds and letters in foreign language lessons by children with autism are considered.

A person with autism generally has difficulty in language learning, obtaining communication, social, and cognitive skills. Due to these challenges, children with autism learn better from visual aids, imitation and structured surroundings that fit their sense perception and routines. They have to deal with the consequences of negative attitude towards people with disabilities in general. Nevertheless, some families, despite having children with severe ASDs, have still managed successful psychological adaptation.It is recognized that children in such conditions better adapt to the environment, develop social skills, and feel more independent and socialized.

Parents and the professionals agree that every child with an autism spectrum disorder is unique and it takes lots of hard work to help a child with autism get the most out of the classroom experience. It also takes, a good dose of structure and understanding that each child has different needsas well as styles of learning.

Interaction with other children will help to obtain out of the classroom experience through games, which allow some children with autism to accept a social interaction. A structured environment can make the child feel secure and more open to learning. The main forms of interactive work are educational interaction of students in pairs and micro groups. Groups study

(C) Semeniuk A., Yezerska I., 2020 